\title{
Governing global telecoupling toward environmental sustainability
}

\author{
$\underline{\text { Jens Newig }}^{1}, \underline{\text { Edward Challies }}^{1,2}, \underline{\text { Benedetta Cotta }}^{1}$, Andrea Lenschow $^{3}$ and $\underline{\text { Almut Schilling-Vacaflor }}^{3}$
}

\begin{abstract}
Telecoupling constitutes a particular class of globalized environmental issues that are neither local-cumulative, nor transboundary, nor concerning global commons, but that arise because of specific linkages between distal regions. Such telecoupled issues, e.g., associated with global commodity chains, waste flows, or migration patterns, have been receiving increasing attention from scholars of global land change science. Although governance research has mostly studied existing institutional responses to these issues, telecoupling opens up a problem-oriented perspective on issues of environmental sustainability that occur regionally, but that arise because of global linkages, and raises novel questions about how such issues are and could be governed in a global architecture. We draw insights from existing literature on globally interconnected phenomena to advance our understanding of governing telecoupling toward environmental sustainability. We first identify and discuss five particular challenges that telecoupling poses to global environmental governance: knowledge deficits, divergent interests, high transaction costs of cooperation, the weak legitimacy base of current governance arrangements, and policy incoherence and fragmentation. Second, we review conceptual literature that meaningfully address the governance of telecoupling, while utilizing differing terminologies, for example, through reference to "flows," "chains," or "multiscalar" issues. Building on this, we elaborate on how currently debated governance approaches respond to the identified challenges. We conclude with a brief note on where we believe the discussion on governance of telecoupling stands, and where we see directions for future research.
\end{abstract}

Key Words: environmental flows; fragmentation; global commodity chains; global environmental governance; inter-regional connectedness; scale

\section{TELECOUPLING CHALLENGES ESTABLISHED NOTIONS OF GLOBAL ENVIRONMENTAL GOVERNANCE}

The concept of telecoupling, which has emerged out of land change science (Liu et al. 2013, Eakin et al. 2014, Friis et al. 2016), and which is rapidly gaining ground in the academic literature on global environmental change, poses challenges for our understandings of environmental governance. Telecoupling is concerned with how human-induced processes in one part of the globe impact in specific ways on a distant part (or parts) of the world. This kind of "global inter-regional connectedness" (Kissinger et al. 2011) means that sustainability in one place is often interdependent with sustainability in particular distant places and systems. What makes telecoupling a relevant concept is that it allows for the description of flows between geographically distant places in a common language that helps to understand the environmental and social impacts of these flows. Many illustrations of telecoupling relate to global commodity chains. In the case of the soy chain between Brazil and Germany, for example, Brazilian soy is fueling German meat production, and this connection is driving both nitrate accumulation in Germany and deforestation in Brazil (Lenschow et al. 2016). In the case of global "e-waste" flows, the shipping of electronic waste from Europe to Africa and Southeast Asia contaminates receiving environments and jeopardizes the health of local communities (Oswald and Reller 2011, Stevenson 2017). However, the concept also applies beyond commodity chains and material flows. For example, human migration flows involving labor migrants or refugees in stable corridors following certain social network structures may generate environmental impacts at points of origin and destination (Nawrotzki et al. 2015). Similarly, flows of tourists may produce negative environmental impacts in geographically distant tourist destinations as well as through the infrastructures that enable such movement (Boas et al. 2018, Phoochinda 2018). Furthermore, global financial and capital flows may drive environmental degradation in countries hosting foreign direct investment (Vongpraseuth and Choi 2015, Bokpin 2017).

In principle, global linkages and their impacts on environmental sustainability have been addressed in the globalization literature for some time, partly in the form of critiques of the environmental impacts of global trade, especially "unequal exchange" between developed and developing countries (Sonnenfeld and Mol 2002, Krapivin and Varotsos 2007, Jorgenson 2016, Frey et al. 2019). However, it has been argued that "globalization as a diffuse, aggregated process of economic intensification and connectivity has not yet been specified in terms of particular causal socialenvironmental chains specific to a suite of actors, interacting noneconomic and economic flows and feedbacks, and placebased outcomes" (Eakin et al. 2014:143). Hence, telecoupling may help bridge the gap between "diffuse" globalized processes, and strictly regional environmental problems.

The concept of telecoupling proposes a common lens through which to examine and analyze these linkages and impacts. Inspired by notions of "teleconnections" as developed in atmospheric science to denote physical interlinkages across large distances, telecoupling has been developed in global land systems research to refer to human-induced processes that entail biophysical and social consequences in distant places (Reenberg and Fenger 2011, Liu et al. 2013). The concept has proved appealing, and is being rapidly adopted by scholars ${ }^{[1]}$. Within the literature, two broad perspectives have emerged: one in which a focal region forms the main object of research, along with

${ }^{1}$ Research Group Governance and Sustainability, Leuphana University Lüneburg, Germany, ${ }^{2}$ School of Earth and Environment, University of Canterbury, New Zealand, ${ }^{3}$ Jean-Monnet-Chair of European Integration, Osnabrück University, Germany 
incoming and outgoing telecoupled links to distant regions (e.g., Friis and Nielsen 2017); and another perspective that studies the telecoupled flows between two (or more) regions (e.g., Eakin et al. 2014). Whereas the former perspective carries predominantly local governance implications, the latter points to challenges in global governance, which, we suggest, the governance literature does not yet adequately address.

How does the concept, and the phenomenon, of telecoupling challenge our thinking on environmental governance? To date, global environmental governance scholarship has been primarily concerned with the following:

- existing governance arrangements, such as global treaties, how they come about, and how they help to solve environmental problems;

- governance processes, such as participatory, networked, and collaborative governance, and how these may benefit the environment;

- governance structures, such as multilevel and polycentric governance, and how these may benefit the environment;

- particular classes of environmental problems, such as transboundary pollution, and how they can be tackled through bilateral or multilateral action; and,

- global commodity chains and the governance of such chains by private, public and nongovernmental actors.

The field of global environmental politics and governance has been maturing in recent years, as witnessed by a number of handbooks and review articles (Speth and Haas 2006, Dauvergne 2012, Harris 2014, Pattberg and Widerberg 2015). However, in their recent overview of the field, Dauvergne and Clapp (2016:7) warn that there is too much work on "theoretical refinements of existing governance arrangements and the intricacies of institutional dynamics" and that the literature therefore "tends to miss important developments regarding new environmental issues that as yet are not subject to sophisticated governance frameworks." The telecoupling concept in fact provides for a perspective that starts from environmental issues arising from specific global inter-regional linkages. Rather than a priori engaging with refinements of existing governance arrangements, it brings focus to the need for, and the design of, effective institutions given globally telecoupled interconnections. In this sense, the telecoupling concept adds a new perspective to the (environmental) problems caused by specific global interactions. Different forms of governance are potentially addressing such phenomena, while others are likely going unaddressed. Taking a telecoupling perspective on environmental issues, it is crucial to understand the telecoupled flow and its environmental implications, and then to consider different (potential) governance responses in conjunction (rather than studying and understanding particular governance instruments in the first instance). An emerging body of literature is now beginning to address the governance of telecoupling (Challies et al. 2014, Lenschow et al. 2016, Eakin et al. 2017, Liu et al. 2018, Oberlack et al. 2018, Newig et al. 2019), and could be seen as a response to the deficits identified by Dauvergne and Clapp (2016).

We aim to contribute to the literature on global environmental governance in a two-fold manner. After laying out our understanding of governance concerning telecoupling, we discuss five particular challenges that telecoupling poses to global environmental governance. Arguably, telecoupling demarcates a unique class of environmental problems, which are driven by distant interlinkages. Subsequently, we review conceptual literature that meaningfully address the governance of telecoupling, recognizing that different fields of study describe this phenomenon in quite different terms. We seek to map and compare the different conceptual lenses on telecoupling, asking: What specific empirical phenomena are described, and through which conceptual lenses ("flows," "chains," "multiscalar" etc.)? And what governance arrangements are described and/or called for? Building on this, we elaborate on how currently debated governance approaches respond to the identified challenges. We conclude with a brief note on where we believe the discussion on the governance of telecoupling stands, and where we see directions for future research.

\section{DEFINING GOVERNANCE IN RELATION TO TELECOUPLING}

Telecoupling has been described as an essentially "ungoverned" process because unintended negative consequences of telecoupling emerge beyond the reach of established governance arrangements: governance institutions in one region cannot cope with implications in distant, linked regions; likewise, higher level institutions are missing (Eakin et al. 2014). However, human activity almost never operates in an institutional void. Trade regimes exist, and virtually every country has a system of environmental governance in place. In fact, telecoupling is often enabled or even instigated by governmental action, as has been illustrated by Hamilton-Hart (2015) with the example of Southeast Asia's state-supported palm oil industry ${ }^{[2]}$. And yet, these existing governance institutions may do little to cope with the negative externalities caused by spatially-and often also socially and institutionally (Eakin et al. 2017) — distant processes. Therefore, we focus here on those instances and institutions of governance that explicitly respond to telecoupling, addressing its negative environmental externalities. Governance in this sense targets leverage points to mitigate sustainability problems created by telecoupling across the connected regions, or in spillover regions (Liu et al. 2018). Governance here ranges from state-based environmental measures, which also potentially include private and civil society actors, to nonstate actor-driven and multistakeholder initiatives (Lenschow et al. 2016). Telecoupled systems, in particular, tend to be increasingly populated by private sector-led governance arrangements (Cashore 2002, Gilligan and Vandenbergh 2020).

This understanding of governance largely aligns with the vast literature on environmental and sustainability governance (e.g., Lemos and Agrawal 2006, Biermann 2007, Meadowcroft 2007 , Jordan 2008, Newig and Fritsch 2009). Like environmental law or environmental policy, environmental governance implies the aim to safeguard the environment and to help make development more environmentally sustainable. We may therefore define environmental governance as the "totality of interactions among societal actors aimed at coordinating, steering and regulating human access to, use of, and impacts on the environment, through collectively binding decisions. Environmental governance arrangements may be directed towards a range of causesincluding conservation and environmental protection, spatial and 
Fig. 1. Environmental problems classified according to their spatial / jurisdictional extent. A + sign denotes that the criterion mentioned in the left column is of relevance to the spatial extent described; a - sign denotes that this is not the case; brackets denote that the criterion is somewhat important $(+)$ or unimportant $(-)$. The white arrows and the circle denote the spatial extent of the environmental problem.

\begin{tabular}{|c|c|c|c|c|}
\hline Spatial extent & Local-cumulative & Transboundary/regional & Telecoupled & Global commons \\
\hline $\begin{array}{l}\text { Jurisdictions } \\
\text { affected }\end{array}$ & $\begin{array}{l}\text { Single } \\
\text { (national or } \\
\text { subnational) }\end{array}$ & $\begin{array}{c}\text { Multiple } \\
\text { (bi- or multilateral) }\end{array}$ & $\begin{array}{c}\text { Multiple } \\
\text { (bi- or multilateral) }\end{array}$ & $\begin{array}{c}\text { Many } \\
\text { (multilateral/ } \\
\text { international) }\end{array}$ \\
\hline $\begin{array}{l}\text { Spatial } \\
\text { disconnect }\end{array}$ & - & - & + & + \\
\hline $\begin{array}{l}\text { Geographic and } \\
\text { culturalproxim- } \\
\text { ity; history of } \\
\text { collaboration }\end{array}$ & + & $(+)$ & $(-)$ & $-/(+)$ \\
\hline $\begin{array}{l}\text { Data availability } \\
\text { and traceability }\end{array}$ & + & $(+)$ & $(-)$ & $(-)$ \\
\hline $\begin{array}{l}\text { Link to } \\
\text { established } \\
\text { legitimacy base }\end{array}$ & $\begin{array}{c}+ \\
+ \\
\text { (Local elections) }\end{array}$ & $\begin{array}{c}(+) \\
\text { (Bi- or multilateral } \\
\text { agreements) }\end{array}$ & $(-)$ & $\begin{array}{c}\stackrel{(+)}{(\text { International }} \\
\text { agreements) }\end{array}$ \\
\hline $\begin{array}{l}\text { Established } \\
\text { governance } \\
\text { literature }\end{array}$ & $\begin{array}{c}+ \\
\text { (Environmental policy / } \\
\text { governance) }\end{array}$ & $\begin{array}{c}+ \\
\text { (Transboundary / } \\
\text { regional governance) }\end{array}$ & $\begin{array}{c}- \\
\text { (Emerging, } \\
\text { heterogeneous) }\end{array}$ & $\begin{array}{c}+ \\
\text { (Global environmental } \\
\text { politics / governance) }\end{array}$ \\
\hline
\end{tabular}

land use planning, (sustainable) management of natural resources, and the protection of human health-and operate across scales to address local and global environmental problems" (E. Challies and J. Newig, 2019 blog, https://sustainabilitygovernance.net/2019/06/14/what-is-environmental-governance-aworking-definition/).

\section{CHALLENGES OF GOVERNING TELECOUPLING TOWARDS SUSTAINABILITY}

We argue that globally telecoupled phenomena pose considerable challenges to effective governance toward environmental sustainability. It appears that these challenges, while affecting various kinds and cases of telecoupling, are distinctly different from other environmental problem settings (see Fig. 1 for an overview). Building on the established distinction between three broad kinds of global environmental problems (O'Neill 2009; for a similar typology see Turner et al. 1990), we highlight the particular governance challenges posed by telecoupling. Localcumulative problems occur within a given jurisdiction but have cumulative global effects, e.g., biodiversity loss or deforestation. Transboundary environmental problems cross and/or spill over from one jurisdiction to another, such as water pollution and biodiversity problems in cross-border river basins and nature protection areas, or air pollution in neighboring jurisdictions (Earle et al. 2010, Perrin and Bernauer 2010). Finally, global commons issues refer to effects or impacts on, for example, the global atmosphere or the oceans, which are not territorially bounded.

Arguably, telecoupled environmental problems represent a unique class of global environmental problem (see Fig. 1). First, there is the distinctive, yet often complex, spatial extent of telecoupling. Local to regional, place-bound environmental problems (such as air pollution from urban traffic) may be effectively addressed at the local or national level. Similarly, transboundary environmental problems (such as cross-border commuter traffic or water pollution) share a common spatiality (or at least a spatial proximity) that fosters collaboration in solving environmental problems between neighboring jurisdictions (Blatter 1997, Plangger 2019). However, this is different for globalized environmental issues, which are typically characterized by a spatial disconnect. Telecoupled issues are also distinct from global commons issues such as global climate change, biodiversity loss, or marine pollution, in that they are more specific and seldom directly affect large parts of the globe. Rather than focusing on global institutional solutions for the protection of international common pool resources (e.g., Haas et al. 1993, Barkin and Shambaugh 1999), telecoupling directs our attention to issues concerning (sub)nationally owned and managed resources, which are used, exploited, or impacted on by actors from other parts of 
the world. Therefore, classical instruments of global environmental politics and governance, such as international environmental agreements, form part of the overall governance context as they may partially regulate telecoupled flows. However, they may not be the most targeted instruments to address the specific local environmental implications arising from telecoupled relations between distant regions. Certain bilateral arrangements, such as safeguards attached to international development aid or World Bank loan conditionality, may target environmental protection in specific regions (e.g., Martinot 2001, Kareiva et al. 2008, Corson 2010, Restivo et al. 2018), but this is not always the case, and where such arrangements do exist, they are not always effective in achieving these environmental goals (Mak Arwin and Lew 2009, Buntaine and Parks 2013, Shandra et al. 2016, Sommer et al. 2017).

All in all, environmental effects of telecoupling sit somewhere between transboundary and global issues. Telecoupled environmental problems share the specific sending/receiving relationship with transboundary issues, and the smaller number of involved jurisdictions. With global issues, they share the spatial disconnect and the often more complex causal chains, making data availability and traceability more difficult. Strikingly, in contrast to the other three described settings, there is no established body of literature on the governance of telecoupling (Eakin et al. 2017).

So what is it that makes the governance of telecoupling particularly challenging? On a very general level, the "disconnect between the problem origin and outcome challenge efforts at problem resolution" (Eakin et al. 2014:143). Based on a careful reading of the literature, we identify five major reasons why telecoupled sustainability issues pose particular challenges for effective governance responses. Although none of these challenges are unique to telecoupling, they do tend to be particularly pronounced in relation to telecoupled issues.

1. Knowledge deficits: In order to effectively address the externalities of telecoupling, the telecoupled flows and cause-andeffect-relationships ought to be known in the first place. However, compared to local or transboundary governance issues, which are characterized by spatial proximity, the distances involved in telecoupled issues impede information feedback and make flows and effects less visible. It is often difficult if not impossible to trace flows and establish causality in complex telecoupled chains. This is partly due to fundamental issues of unpredictability in complex systems, due to the multitude of potential intervening factors, such as the lack of transparency and accountability in many commodity chains, or the lack of relevant knowledge and data. This makes it difficult to identify responsibility or hold certain actors accountable. Moreover, it may not be obvious where costs and benefits occur. In the field of global value chains and networks, there is a growing literature on the issue of transparency and traceability (see, e.g., Mol and Oosterveer 2015, Gardner et al. 2019).

However, there are a number of factors working against successful governance interventions. One is the sheer complexity of chains and interlinked processes, which requires interdisciplinary analyses. Moreover, certain economic interests may oppose full transparency. For example, soy traders may not wish to disclose their suppliers for fear of losing their competitive market position.
Furthermore, while databases tracking biophysical processes like biodiversity loss or deforestation offer important insights about the environmental impacts of production and trade, reliable data on social dimensions often do not exist. Consequently, flow-based governance arrangements often miss important issues, such as local actors' loss of access to land, water, and other resources.

2. Diverging interests: The distant linkages characteristic of telecoupled phenomena often require bilateral or multilateral cooperation over greater distances. Such cooperation relies on identification of mutual interests among the involved parties (Keohane 1984). Unlike transboundary issues, where spatial proximity more easily allows for cooperation between different interests, distant regions less likely share common interests that could underpin joint solutions to telecoupled sustainability issues. First, given geographical and often cultural distance, a common value basis is less likely than in neighboring regions. For example, in the case of Brazil-Germany soy trade, German environmental groups are often concerned with the protection of rainforests, whereas local Brazilian concerns also focus on pesticide pollution and access to land and clean water. European importers and retailers have usually delivered certified soy whenever their clients have required this, however, demand for certified soybeans has been relatively low and the main certification standards ProTerra and the Round Table on Responsible Soy (RTRS) have suffered from surplus production of certified soy. In addition, as in many other supply chains, the soy chain has seen fierce contestations about the distribution of costs and benefits of certified products between southern producers, certifiers, and retailers (see Schleifer et al. 2019). In comparison to products that are consumed directly, like coffee or cocoa, consumer demand for sustainable "hidden commodities" like soybeans has been low, and the physical distance between soy-producing and soy-consuming countries aggravates this invisibility and contributes to manifesting different points of view. Diverging interests also explain why international initiatives to compensate for regional conservation efforts have often failed, as was the case with Ecuador's YasuniITT initiative. Here, it was proposed that the international community partly compensate Ecuador for foregone financial benefits incurred by not exploiting an oil field underneath the Ecuadorian Amazon rainforest, with the aim to both conserve biodiversity and contribute to climate change mitigation. Yet the innovative and ambitious plan failed because of a lack of interest on the part of potential financial contributors (López Rivera 2017).

3. High transaction costs: Cooperation not only requires shared interests, it becomes more unlikely the higher the transaction costs involved in establishing cooperation (Jager 2016). Transaction costs are likely to be lower if there is a history of prior collaboration among states, and overall trustful relationships (Keohane 1984). This has been described as a typical "success" factor in the formation and delivery of transboundary environmental governance (Bernauer 1997, Jager 2016). Transboundary environmental governance has been described as offering "superior conditions of scale" for the management of common pool resources and environmental problems (Conca 2012:127, Haas 2016). Addressing environmental problems on the regional scale is characterized by "proximity, [and] shared histories of cooperation or conflict" among interacting parties (Balsiger and Prys 2016:240). Cases in point are the joint 
management of river basins, e.g., the International Commission for the Protection of the Rhine, or the Convention on Long-Range Transboundary Air Pollution (LRTAP). In contrast, for telecoupled issues, bilateral or multilateral agreements are less likely to be in place; and if they do exist, they are less likely to be effectively implemented, for the same reasons. What is more, the often complex set of actors and jurisdictions involved increases transaction costs of effective cooperation. Even compared to global environmental problems, telecoupled issues may exhibit higher transaction costs, because in the international arena, traditions of rulemaking through international organizations already exist. However, bilateral or multilateral agreements are perhaps capable of addressing problems emerging from telecoupling because of their relative specificity. Research in global environmental governance also points to the global diffusion and convergence of norms, principles, and policies developed at the level of international organizations, which may also trickle down to various parties to telecoupled relations (Holzinger et al. 2008, Jörgens et al. 2014).

4. Weak legitimacy base: In so far as efforts to govern telecoupling occur in polycentric, transnational regulatory regimes with a strong presence of nonstate regulators, their legitimacy and accountability have been highly contested (Black 2008, Oosterveer 2018). Private-actor based transnational environmental governance has been touted for being potentially more proactive than state-based governance, for example, in the climate regime (Gilligan and Vandenbergh 2020). However, whereas national legislation and international environmental agreements rest on established sources of legitimacy, attempts to govern telecoupled issues are particularly problematic in that respect. Scholars have criticized the lack of legitimacy of multistakeholder initiatives on agro-commodities like palm oil and soybeans (Cheyns 2011, Fuchs et al. 2011, Elgert 2012, Fortin 2013, Schleifer et al. 2019). Even in the case of the Forest Certification Standard (FSC), which has been considered a leader among sustainability standards for its democratic inclusion of indigenous peoples and civil society organizations, scholars identified important legitimacy deficits (Meadows et al. 2019). Weak legitimacy of private governance approaches is evident in that groups subjected to governance are largely excluded from decision making, that information is usually tightly controlled, and that the affected public is often not able to hold decision makers accountable if a given governance institution performs badly.

Multistakeholder initiatives are an increasingly favored mode of governance, but, whether they involve state actors or not, they typically lack the legitimacy to take decisions that would effectively address telecoupled sustainability issues. This is exemplified by the Roundtable on Sustainable Palm Oil and the Round Table on Responsible Soy (Schouten and Glasbergen 2011, Okereke and Stacewicz 2018). As the sustainability issues in both of these industries are often very controversial, actors on both sides of the spectrum, those striving for more stringent and those striving for more lax regulation, often abandon the respective governance initiatives. In turn, corporate-led sustainability governance is often weak with regard to both procedural development and implementation in practice. The auditing of corporate initiatives also typically relies on self-reporting, and data on the effectiveness of such initiatives are usually scarce.
5. Policy incoherence and fragmentation: Arguably, the effective functioning of environmental governance arrangements relies on a certain degree of coherence among the involved policies and institutions (May et al. 2006). Implementation of highly antagonistic policies is in any case almost impossible. Although this is an issue for many kinds of environmental problems, it is particularly relevant in telecoupled settings. Both vertical coherence (in multilevel systems) and horizontal coherence (across states and policies) may be problematic, given likely differences in policies in sending and receiving systems as well as with higher order policy, e.g., WTO trade rules (Reyes-Mendy et al. 2014). Such incoherencies may be due in part to diverging interests as discussed above. The recent trade agreement between the EU and Mercosur provides an example of a policy that fails to align trade and sustainable development, as Brazil successfully resisted attempts by the European negotiators to strengthen sustainability and human rights provisions. Furthermore, governance arrangements targeting telecoupled systems are likely to suffer from high degrees of fragmentation (Zelli and van Asselt 2013), given the prevalence of private and multistakeholder initiatives in sectors such as the certification of biofuels (Schleifer 2013).

\section{CONCEPTUAL LENSES ON GOVERNANCE OF TELECOUPLING}

Having identified five broad challenges of governing telecoupling toward sustainability, where might one look for responses to these challenges? We begin by reviewing areas of scholarship that we deem of importance in understanding the governance of telecoupling (see Table 1 for an overview). Although these approaches do share a concern with the governance of globally telecoupled environmental issues, we see a still limited cumulation of knowledge, in the sense that the different scholarly communities do not tend to take account of and build on one another toward a comprehensive understanding of global environmental governance. By addressing the potential that each area of scholarship holds for understanding the governance of telecoupling, we aim to pave the way for more systematic and comparative empirical research in the field. In identifying the areas of scholarship discussed below, we acknowledge that these may overlap to some degree. Nevertheless, each brings specific contributions to the challenge of governing global telecoupling.

\section{Global environmental governance}

Telecoupled phenomena rarely emerge in clearly defined interstate contexts, but rather in multilevel, multistakeholder, and cross-sectoral contexts. The early work of global environmental governance (GEG) scholars, rooted in the literature of international relations, tended to analyze environmental regime formation under conditions of state sovereignty and diverging interests. Not least because of the influence of the International Human Dimensions Program on Global Environmental Change (IHDP), the empirical focus widened to institutional effects and effectiveness (e.g., Miles et al. 2002). International environmental institutions were thought to influence human behavior as not only utility modifiers and enhancers of cooperation, i.e., helping overcome diverging interests, but also as offering legitimacy bases in bestowing authority and facilitating learning (Mitchell 2013). Analytically, GEG scholars began to acknowledge the critical role of a wide set of public and private actors at different levels of 
Table 1. Overview of literature strands important to the governance of telecoupling

\begin{tabular}{llll}
\hline \hline $\begin{array}{l}\text { Literature } \\
\text { strand }\end{array}$ & $\begin{array}{l}\text { Main contribution to } \\
\text { understanding governance } \\
\text { of telecoupling }\end{array}$ & $\begin{array}{l}\text { Contribution to addressing telecoupling } \\
\text { governance challenges }\end{array}$ & $\begin{array}{l}\text { Who governs, and with what } \\
\text { goal? }\end{array}$ \\
\hline
\end{tabular}

\begin{tabular}{ll}
\hline Global & Helps to understand \\
environmental & governance arrangements \\
governance & beyond nation state
\end{tabular}

Transnational Helps to understand how private governance flows of products are regulated by private certification, standards, and commitments.

Global commodity chains

\section{Describes how key actors} coordinate economic chains often private and market-based, can reach to link distal regions and processes from production to consumption.

Environmental Sociological perspective, flows describing flows but also addressing governance challenges.

Critical

political economy of the global Precise descriptions of production chains and their adverse environmental effects.

environment

Scalar governance

Telecoupling and land system science

\section{International regimes may reduce transaction costs, build trust, and support learning, all of which could help overcome initial conflicts. Institutional interplay, incoherence, and fragmentation are a second challenge addressed through actor- based (e.g., venue shopping) and institutionalist (e.g., "fit" and integrated management) lenses.}

Overcomes challenges of transaction costs, as private governance crosses scales and jurisdictions; helps to identify existing knowledge gaps; more limited contribution to bridging divergent interests by developing multistakeholder initiatives. Commodity chain governance, which is

\section{Mostly state-based} governance is supposed to alleviate environmental sustainability problems. Links to experts (epistemic communities), NGOs, multinational corporations have been addressed as well.

Private actors, mainly corporations and civil society organizations; mixed goals, often responding to critique or consumer preferences.

Mostly private firms; in order to coordinate chain cross-border networks of actors (producers, suppliers, traders, and buyers) and processes that are often out of public view and beyond the scrutiny of any specific government or state-based governance instrument.

Overcomes challenges of transaction costs (through networked collaboration and trust building) and divergent interests (through brokering activities of networked actors). Draws attention to the displacement of environmental harms from the Global North to the Global South; sheds light on diverging interests embedded in unequal power relations. Advocates for radical and systemic change.

Bridges diverging interests (because ideally, one governing body would deal with conflicts arising from spatial spillovers), and lower transaction costs once governance mechanisms are institutionalized. Such institutions could also provide legitimate decision-making structures.

Provides an analytical framework to analyze the interaction of different governance instruments and to identify shortcomings in existing governance arrangements. activity, but also (with public sector and civil society actors) to address certain negative externalities.

A wide range of actors considered with a goal of alleviating environmental sustainability problems. Focus on structures of market failure, state capture, and behavioral ethics.

Mostly state-based governance is supposed to alleviate environmental sustainability problems.

Very heterogeneous, previous Debates on the governance of literature outlines the lack of telecoupling would benefit from effective governance for addressing local problems exacerbated by telecouplings.

\author{
Focus on specific institutional \\ designs of international/ \\ transboundary agreements with \\ little attention to local \\ circumstances; associated \\ cognitive distances and \\ knowledge gaps.
}

Not enough research into public and private interactions, cross-sectoral relations, and local complexities.

Focuses on within-chaingovernance and interfirm linkages, little research on broader institutional interactions and environmental impacts.

Relatively abstract about specific problem settings and governance mechanisms.

Focus on systemic and behavioral failures in the global capitalist economy "above" telecoupled places and flows; literature is limited regarding the nuances of governance responses.

Does not capture spatial disconnects, where drivers and impacts operate at different scales. a more nuanced treatment of governance. governance (e.g., Haas 1990, Princen and Finger 1994). This work examined the influence of ideas (discourses, frames, and knowledge, e.g., Young 1998, Zürn 1998), and reflected on hard and soft policy instruments, thus establishing links to the literature discussed below.

Also, with respect to the analysis of cross-issue and cross-sectoral linkages and the associated challenges of policy incoherence and institutional fragmentation, which are characteristic of telecoupling, the GEG literature has developed important insights, drawing much inspiration from the IHDP project (Young 1996, 2002, Young et al. 2008). Empirical work examines the greening of international economic institutions like the WTO and the World Bank (cf. Charnovitz 1997, Eckersley 2004), international environmental policy integration and environmental mainstreaming (e.g., Nilsson et al. 2009), policy coherence among international organizations (e.g., Oberthür and Gehring 2006, Oberthür and Stokke 2011), and nexus politics (e.g., Hoff 2011, Boas et al. 2016). Going beyond issues addressed in the GEG literature, telecoupled phenomena point to cognitively distant connections, often escaping the perception of actors involved and thus eluding obvious institutional solutions. Bridging such geographic and related cognitive distances might require integration at the truly global level, as reflected in political and academic discussions about the need for a global environmental organization equipped with more authority than the United 
Nations Environment Programme (Esty 1994, Biermann and Bauer 2005), and the pursuit of earth system governance (ESG) (Biermann 2007, 2014). However, the all-encompassing perspective of ESG results in complexity risking institutional overload, which undermines problem solving approaches targeted at particular telecoupled settings. Nevertheless, recent ESG scholarship aims to consider particularly growing interconnections and global variation that are central to telecoupling (Burch et al. 2019). Similarly, Young and Stokke (2020) formulate response strategies to tackle instances of institutional overload and, for instance, argue that procedures facilitating interplay management may help to achieve regulatory coherence even in highly complex problem settings.

\section{Transnational private governance}

Private governance initiatives are particularly relevant for shaping and regulating flows between sending and receiving systems involved in telecoupled relations. An array of private initiatives are playing an increasing role in flow-based governance: certification and labelling, corporate sustainability commitments (for instance, to deforestation-free supply chains), multistakeholder agreements, grievance mechanisms, and information disclosure (Dauvergne and Lister 2012, Mol and Oosterveer 2015). These initiatives have often emerged in response to feedback loops about localized negative externalities of corporate activity. Although private and multistakeholder initiatives have influenced both local production processes and consumer behavior, their effectiveness on the ground is still under-researched (Thorlakson et al. 2018, Gardner et al. 2019).

For our purposes, the private governance literature is important, because it sheds light on the legitimacy, content, and functioning of private initiatives and it comprehensively discusses shortcomings of corporate-led or multistakeholder governance initiatives. These include limited uptake, the low stringency of many schemes, disregard for broader socio-political issues, weak supply chain transparency, and the dominant role of corporate interests in such initiatives (Pattberg 2006, Elgert 2012, Challies 2013, Derkx and Glasbergen 2014, Vos and Boelens 2014). The respective findings help to understand the role that private governance plays within broader governance arrangements shaping telecoupled phenomena, which is important to better understand existing shortcomings and to reflect on alternative scenarios that might better address negative externalities.

\section{Governance of global commodity chains}

Global commodity chain (GCC) research examines networks of actors, particularly producers, consumers, and intermediaries, in the global economy (Gereffi 1994, Bair 2009). GCC analyses have focused on cross-border interfirm relations (Gereffi et al. 2005), exploring how firms shape chain structure and dynamics, and therefore might offer valuable insights for the governance of specific telecouplings. Although much GCC governance research has focused on within-chain interfirm coordination (Humphrey and Schmitz 2001, Gibbon et al. 2008), this has shed light on how powerful corporate actors can drive chain functions (Gereffi 1999, Dolan and Humphrey 2004). Despite an enduring interest in interfirm interaction, GCC studies have also recognized the influence of external governing actors (Humphrey and Schmitz 2001, Kaplinsky and Morris 2002), and increasingly turn to broader socio-political governance questions.
Some GCC scholars have called for a governance perspective, arguing that chains "can both undermine government policy but also offer new leverage points for government initiatives" (Humphrey and Schmitz 2001:21). To a great extent, GCC governance research has focused on the role of nonstate governing actors, and drawn attention to the limits to private sustainability governance (e.g., Cheyns 2011, Dauvergne and Lister 2012, Challies 2013). Recent research has sought to integrate the vertical (flow) and horizontal (place) dimensions of chains for a more systematic treatment of local-level social and environmental impacts (see Bolwig et al. 2010).

The concept of governance continues to evolve and widen in GCC work. Havice and Campling (2017) begin to bridge the chain governance and environmental governance literature through conceptualizing "environmental conditions of production" as central to GCCs, although they do also remain primarily concerned with firms and firm strategies. Bush et al. (2015) offer a helpful distinction between: (1) sustainability governance in chains, by firms to manage their environmental performance; (2) sustainability governance of chains, by lead firms to influence performance of other chain actors; and (3) sustainability governance through chains, by different actors (internal and external to chains), to "collectively steer sustainable production and consumption practices" (Bush et al. 2015:13). Such a typology of chain governance offers a potentially useful perspective on the role of firms and other private actors in governing telecoupling (Newig et al. 2019).

\section{Governance of environmental flows}

The notion of flows, which is so central to telecoupling, has been a focus of extensive research by (environmental) sociologists, who have sought to describe the diffusion of social structures under globalization since the late-1990s (Oosterveer 2018). Social theory was to be made "less static, more fluid, and more directed towards flows and networks, instead of social systems and in particular the nation state" (Spaargaren et al. 2006:ix). Drawing on seminal contributions by Castells (1996), Urry (2003) and others, Mol and Spaargaren (2012) advanced a specifically environmental perspective, centered on networks and flows as key constituting categories of global modernity. They argue that "if we are to understand today's global environmental politics and governance we have to understand how networks and flows function and can be governed" (Mol and Spaargaren 2012:194). Thus, a key governance challenge is the regulation of flows rather than regulation of localities, in the context of emergent "deterritorialized forms of authority" (Mol and Spaargaren 2012).

An environmental flows perspective points away from traditional state-based governance, which bears the aforementioned problems of transaction costs and diverging (geo-political) interests, and toward flow-based governance arrangements. Identifying network actors such as NGOs, private companies, and transnational bureaucracies (Oosterveer 2018) as potentially important governing agents, flow-based governance may have the potential to overcome challenges of transaction costs, e.g., through networked collaboration and trust-building, and divergent interests, through brokering activities of networked actors.

However, it should be noted that the networks and flows perspective has been subject to debate within environmental 
sociology because of its reformist (rather than transformative) agenda (York et al. 2010), having essentially emerged from an ecological modernization paradigm (Mol et al. 2013). In a similar vein, while Sikor et al. (2013) observed a shift toward flowcentered approaches in global land governance, they highlighted shortcomings of flow-centered arrangements, in particular as the latter themselves may generate land uses involving new forms of social exclusion, inequity, and ecological simplification.

\section{Critical political economy of the global environment}

A considerable body of work in the broad tradition of critical political economy has addressed globalization (e.g., Evans 1997, Buckley and Ghauri 2004, Sheppard 2016). Within this tradition, literature on ecologically unequal exchange has drawn attention to the spatial asymmetric distribution of environmental harms between regions in the Global North and the Global South (Hornborg 1998, Rice 2007). Scholars of ecologically unequal exchange have challenged the Kuznets curve hypothesis, which posits an eventually decreasing environmental impact of economic growth, arguing that this model does not account for how wealthy countries export environmental harms and externalize environmental costs onto less wealthy countries, thus exacerbating global environmental disparities (Rosa and Dietz 2012, Jorgenson 2016, Givens 2018, Frey et al. 2019). This strand of literature draws on world systems theory, but it also diverges from it in explicitly focusing on environmental issues and interactions among locally based extractive and productive systems (Bunker 1984, Givens 2018), as well as exports of agricultural products (Sommer et al. 2019, Shandra et al. 2020). Scholars that link global capitalism with "glocal" environmental problems have meticulously traced the distal unsustainability effects of consumption patterns through global production chains (Dauvergne 2008, Dauvergne and Lister 2010, Clapp and Dauvergne 2011).

Work in this tradition is specifically concerned with justice dimensions within telecoupled systems, and it has the potential to link research on commodity chains with work on global environmental governance and politics. Political economy perspectives offer analysis and critique of the manifold environmental impacts of globalization and consumerism. We are reminded that "[p]romoting green products and sustainable lifestyles is only scratching at the surface of a problematic capitalist world order built on ever-expanding economic growth, consumption, and markets, and efficiencies and profits realized by distancing and externalizing the environmental and social costs of producing, using, and replacing consumer goods" (Dauvergne 2010:8). In consequence, most of the authors from this strand share the position that reformist approaches are not enough for addressing the profound problems related to the current capitalist/ consumerist system and that we rather need systemic transformation.

\section{Scalar and multilevel governance}

A core challenge of telecoupling for environmental governance lies in the fact that causes and environmental consequences occur separately in space. The literature on scalar and multilevel governance explicitly deals with such spatial disconnects. Early works in environmental federalism (Oates 2004) asked at which jurisdictional level different environmental problems should be governed. Given spatial externalities, or "spillovers" of local action across jurisdictional boundaries, it was advocated that governance scales be chosen to encompass the causes and the consequences of environmental problems (Young 2002). Linking institutionalist with social-ecological thinking, scholars advocated for the redesign of institutions to fit them to environmental problems (Galaz et al. 2008), the paradigmatic example being river basin authorities to govern (environmental) issues within the confines of a river basin. This aligns with the notion of functional, problem-specific "type II" systems of multilevel governance (Hooghe and Marks 2003). Such scaleadapted governance institutions potentially bridge diverging interests (because ideally, one governing body deals with conflicts arising from spatial spillovers) and, perhaps most importantly, can reduce transaction costs once governance mechanisms are institutionalized. Such institutions may also provide legitimate decision-making structures.

In response to increasingly globalized environmental problems, where local action has remote consequences ("spacial stretching," Young et al. 2006), processes of governance "rescaling" have been observed (Andonova and Mitchell 2010). Where causes and effects of environmental issues are spatially separated, as is typical for telecoupling, simple scalar strategies such as "upscaling" governance institutions, may no longer be effective. Telecoupling thus complicates such notions of scale (Newig and Moss 2017), raising the crucial issue of where to draw boundaries in telecoupled systems (Challies et al. 2014).

\section{Telecoupling and land system science}

Studies of telecoupling have usually focused on the description of specific connections between distant social-ecological systems. The governance of telecoupling is a theme that has recently begun to be addressed within this strand of literature. Previous research on telecoupling has highlighted the considerable complexity associated with the governance of telecoupled phenomena, and identified some key research gaps (Liu et al. 2013, Challies et al. 2014). Scholars have found that telecoupled systems often present a misfit between governance institutions and the social-ecological problems that they are supposed to address, identifying the following challenges: the existence of and interplay between the social, institutional, and physical dimensions of distance; problems of coordination (between private, public, and multistakeholder initiatives, and across scales, issues, and sectors); difficulties in governing spillover effects; problems of traceability; and limited knowledge (Challies et al. 2014, Haberl et al. 2014, Lenschow et al. 2016, Eakin et al. 2017, Friis and Nielsen 2017, Liu et al. 2018). Lenschow et al. (2016) argued that a telecoupling perspective can provide focus and specificity in the application of concepts like globalization, sustainability, and environment, and thereby help to understand the variety of impacts in socialecological systems and identify governance trade-offs among different sustainability dimensions across multiple scales.

In the investigation of existing governance arrangements and challenges, Friis and Nielsen (2017) recommend a flexible and heuristic approach to telecoupled systems. This leaves the question of system boundaries open for empirical investigation, rather than assuming a given geographical entity or administrative unit. Such an approach allows research to focus on different scales, flows, and locations of telecoupled systems, depending on the specific research interest. Eakin et al. (2017) 
identify social pressure, actor capacities, and other factors as mobilizing forces that may foster to governance changes that would encompass telecoupled systems as a whole rather than merely the individual sending and receiving systems. Oberlack et al. (2018) draw links between telecoupling and polycentric governance by analyzing networks of action situations in which interactions between proximate and distant actors, as well as socioeconomic and ecological processes, cause land use change and affect the sustainability of land systems. The aforementioned methods provide ways for linking place-based analysis of land change with process-based analysis of land governance.

Despite these important contributions, it seems clear that challenges remain. For example, several authors have argued for the need to tighten feedback loops between sending and receiving systems in order to address negative externalities (Eakin et al. 2014, 2017, Haberl et al. 2014). However, Challies et al. (2014:37) argue that responses to the tightening of feedback loops "are likely to be slow relative to the flexibility and mobility of transnational capital." In summary, we identify much of value in recent and emerging literature on the governance of telecoupling, and we also recognize that this field of research continues to develop its specification of governance challenges and options.

\section{GOVERNANCE RESPONSES TO TELECOUPLING}

As our tour d'horizon of different conceptual approaches has shown, numerous forms of governance arrangements are currently in place, or are being discussed, to address the environmental externalities of telecoupling (see, e.g., Kissinger et al. 2011, German 2014, or VanDeveer 2015, for compilations of governance measures). These range from unilateral action, e.g., mandatory labelling and production standards or duty of vigilance laws, to multilateral action, e.g., technical cooperation, agreements on trade, or environmental standards, and private and multistakeholder initiatives (collaborative and deliberative procedures such as roundtables; labelling, certification, product standards, and other means of private chain governance). How, then, do such governance strategies and the different strands of literature discussing them speak to the challenges outlined above?

1. Knowledge deficits can potentially be addressed with what has been termed "informational governance" (Mol 2006). This might draw, for example, on technologies such as remote sensing and geographic information systems to precisely monitor land use change. As research in global governance and private environmental governance has shown, global sustainability reporting by large companies has been highly selective and often insufficient. Instead, "transformative transparency" might foster sustainability, by providing decision-relevant information, particularly for vulnerable and disempowered actors, and with an emphasis on information as a means to an end, rather than an end in itself (Mol 2006). In addition, the role of legitimate and widely accepted institutions as intermediaries that manage and update sources of information is crucial in informational governance (Mol 2015, Gardner et al. 2019). Moreover, consumer- or retailer-led demand for full information on production processes and places of origin could help. However, more research is also required on the informational and behavioral triggers required to induce sustainable consumption, and the literature on critical political economy may be instructive in this regard. Moreover, global frameworks on corporate social responsibility and on corporate due diligence obligations need to pay more attention not only to employment but also to wider social and environmental impacts of production patterns. Finally, more independent qualitative and quantitative research needs to be funded to more precisely establish causality as regards externalities of telecoupled flows.

2. Diverging interests will not easily be (re)aligned. Nevertheless, the GEG literature offers rich theoretical and empirical material on institutional designs to overcome state-level conflicts under more or less favorable conditions (Barkin and Shambaugh 1999, Miles et al. 2002). Depending on the analytical perspective, authors either highlight institutional designs capable of reducing transaction costs or of facilitating reciprocal bargaining, or they emphasize how institutional issue framing and discursive links help to overcome diverging points of view. Recently, Young and Stokke (2020:16) advised that the "insulation of issue-specific practical cooperation of mutual interest" from conflictual themes or overarching political goals constitutes a viable strategy even in highly conflictual contexts. Turning to diverging interests among nonstate stakeholders, the literature on transnational private governance and on global commodity chains advocates collaborative multistakeholder fora, such as already existing roundtables, for palm oil, soy, and other commodities, which could have the potential to support genuine dialogue and exchange on sustainability values and interests of different actors. However, such fora have so far suffered from issues of legitimacy. Furthermore, they tend to focus on the less controversial issues, which does not contribute to addressing fundamental sustainability problems (Mol 2016). Insofar as diverging interests coincide in a given place, there may be scope for collaborative and deliberative approaches to address some of these differences. Such approaches, which rest on ideals of participation, rational and fair discourse and consensus building, may reconcile competing interests, integrate different kinds of knowledge, deliver effective environmental measures, and achieve positive environmental outcomes (Bächtiger et al. 2018), at least under particular circumstances (Newig and Fritsch 2009, Newig et al. 2018). Acknowledging differences in interests and values among actors in telecoupled systems, Eakin et al. (2017) are hopeful that the recognition of telecoupling along with different kinds of pressures can overcome the prevailing distances in telecoupled systems and lead to substantive changes in governance. As a long-term strategy, one could draw on insights of environmental economists and environmental psychologists to improve informational instruments in inducing inter-regional empathy among consumers. Ultimately, however, diverging interests are likely there to stay, and constitute an important context factor in telecoupling that governance is well advised to take into account.

3. High transaction costs: The reduction of transaction costs has been one of the prime motives for building global environmental governance organizations. The more successful governance interaction there is among telecoupled actors, the easier it is to develop technological co-operation, for example, or bilateral or multilateral trade agreements that effectively address environmental issues. Given the still comparatively high transaction costs of such agreements, an option could also be to focus more strongly on action on the part of the (nation) state. The recent French Duty of Vigilance Law and the Swiss Popular Initiative on Responsible Business, which aim to transfer 
international principles on business and human rights into state law, are a case in point (Bueno 2019). Public initiatives of this sort address existing governance gaps by pressuring private actors (corporations) to assume responsibility for any negative externalities associated with their supply chains. Such approaches reduce transaction costs by acknowledging and drawing on the fact that for transnational private actors it tends to be easier to operate across scales and jurisdictions than for states, which are to a greater extent limited by their jurisdictional boundaries. Likewise, established forms of international decision-making may provide for stronger environmental regulatory frameworks, e.g., through UN rules, which would influence and facilitate decision making in those more complex forms of roundtables or bi-/ multilateral agreements. In addition, the role of civil society might be crucial for improving collaboration and overcoming social and institutional distances across interconnected regions. Scholars have argued that transformation in governance arrangements is more likely when "shadow networks," social networks of actors who share values and priorities, are in place and can be mobilized (see Eakin et al. 2017).

4. A weak legitimacy base is an important issue for collaborative and/or multistakeholder initiatives and roundtables, which tend to replicate existing biases and power imbalances. Distinguishing more strongly between deliberative and decision-oriented fora could be one possibility. The former would comprise inclusive roundtables that mostly serve the function of exchange of knowledge and values as well as learning. The latter would comprise roundtables tasked with decision making, and include governmental actors with clear political mandates, thus providing a stronger role for state-based governance (Lenschow et al. 2016). Generally, a closer link between multistakeholder initiatives and public policy could help avoid capture by powerful actors (Challies 2013). This may include embedding multistakeholder initiatives more explicitly into overarching international frameworks such as United Nations conventions. In addition, scholars of private governance have advocated for a repoliticization of multistakeholder initiatives by opening up certification schemes to greater scrutiny, including the politics that otherwise remain embedded in the back stage of the standards' processes (Fortin 2013). Looking to the literature on critical political economy and ecologically unequal exchange we can anticipate that underlying normative and justice dimensions will need to be explicitly addressed if the legitimacy of these platforms is to increase.

5. Policy incoherence and fragmentation: Work under the auspices of the IHDP highlighted how "interplay among institutions can reflect conscious or unconscious, proactive or reactive, and successful or unsuccessful efforts by policy-makers to develop potential synergies with other institutions while avoiding duplications, redundancies, and conflicts" (cf. Mitchell 2013:6). This insight has influenced a so-called third wave of GEG research looking at policy mainstreaming or integration, policy coherence, and nexus politics (see above). The most visionary, but perhaps idealistic, solution might be earth system governance (Biermann 2014). Although this may likely be too unspecific to tackle telecoupled issues, attempts to intervene in the regulatory sphere of linked institutions will also be relevant for telecoupled phenomena, one option being (international) environmental agreements that allow for trade restrictions where environmental norms are not met. Although most research assumes the dominance of the world trade regime (and there are calls for a greening of the GATT/WTO), Gehring (2007) highlights how international environmental agreements have, under specific circumstances, e.g., the rulings of the appellate body, positively influenced the WTO, which accepted these rules as legitimate. Unless such rules are formulated, the "nondiscriminatory credo" of the WTO applies, and the organization will likely continue to enable telecoupling through promotion of trade with little regard of environmental impacts. The implication seems to be to continue challenging the prevailing free trade paradigm in, ideally international rather than bilateral, environmental agreements. This also means that it may be necessary to embed telecoupled relations in an international normative setting. Attempts at such "orchestration" (Abbott and Snidal 2009) have been emerging for some time but have had limited impact so far (Schleifer 2013). To give a rare example of such orchestration, in the biofuel sector, the European Union assumed an orchestrating role by formally recognizing selected private standards and by making the certification under them mandatory for all imported biofuels (Schleifer 2013). Schleifer concluded that the EU orchestrators could have done a better job by limiting the number of private standards to the most stringent ones. Despite the EU's rather weak orchestrating role in the biofuel sector, disputes in the WTO from the biofuel exporting states Argentina and Indonesia against the EU member states are still pending.

\section{CONCLUSIONS}

In this paper, we have argued that the emergent concept of telecoupling offers a common language and valuable analytical lens for understanding environmental governance challenges arising out of the phenomenon of global inter-regional connectedness. Although the distribution of the impacts of production, trade, and consumption in a globalizing world has been a focus of research from a number of different disciplinary perspectives, we suggest that telecoupling denotes a particular blind spot in this body of work.

In this paper, we have taken stock of different areas of work that speak to some extent to aspects of the phenomenon, and together provide a useful point of departure for developing a more coherent approach to governance of telecoupling. Of particular importance here is the observation that despite all of the work on local, transboundary, and global sustainability governance, there is no established body of literature that deals explicitly with telecoupling as a particular form or configuration of environmental or sustainability problem. Furthermore, the existing literature, which is all to a certain extent relevant to understanding the problem, do not appear to take stock of each other in any systematic way. In this sense, they seem to exist largely as "islands of theorizing" in relation to this topic.

The five governance challenges we identified, knowledge deficits, diverging interests, high transaction costs, weak legitimacy base, and policy incoherence and fragmentation, underscore the need to address telecoupled issues in a specific way if environmental governance is to be globally effective. Emerging from this work, we see the need for further research on the question of governance in relation to telecoupling. This is needed both in order to address the gaps we have described in the literature and in research to date, but also in order to foster more efficient and effective (global) environmental governance solutions. 
First, empirical research should address more systematically the question of what kind of telecoupled issues are likely to give rise to what kinds of governance challenges. Second, we would encourage systematic, interdisciplinary exploration of governance options, by the state, either unilaterally, in collaboration with others, through international conventions, or in collaboration with nonstate actors; and by multistakeholder initiatives and networked approaches. There is a need to better understand which of these are likely to tackle the various governance challenges identified here.

Third, stronger links should be established to scholarly work on modes of governance. What should be the role of collaborative and participatory approaches (Voß et al. 2007, Lange et al. 2013, Newig et al. 2018), and which governance challenges are they likely to address effectively? How can collaborative and participatory governance, which works well on rather local levels, be applied to globally telecoupled governance settings?

Fourth, it is important to acknowledge that telecoupling is typically embedded in existing governance structures that may intentionally or unintentionally create, foster, or maintain telecoupled systems (Newig et al. 2019). With this in mind, how can policies be designed in a way that telecoupling is sustainable from the start? Furthermore, how should governance instruments be applied given a recognition that they will not operate in a vacuum, but rather interact in complex ways with multiple other instruments governing intersecting flows?

Fifth, future research should (more explicitly than could be done here) address the likely trade-offs between the different possible governance solutions that we discuss here. Sixth, even though governance of telecoupling-induced sustainability problems may not operate in a vacuum, it is important to understand why there are governance gaps regarding certain telecoupled flows or sustainability impacts. Demonstrating the existence of such governance gaps and understanding the reasons, potentially because of a combination of the governance challenges we outlined in this article, may help to develop appropriate governance solutions.

Finally, most of the governance literature reviewed here can be classified as "reformist." The general take is that given the unsustainable nature of many telecoupled issues, governance responses need to alleviate issues of unsustainability (or, in the light of the previous paragraph, "design" telecoupling to be sustainable in the first place). What may get lost in these considerations is the need for more fundamental transformation toward sustainability, rather than mere reform. Arguably, both should have their place in the debate on governing global telecoupling toward environmental sustainability.

We hope that our conceptual structuring of the governance literature as it pertains to telecoupling can guide more systematic empirical and conceptual research in this emergent field. This is important, we argue, if work on governance for sustainability is to tackle effectively the quite specific inter-regional linkages and interdependencies that characterize environmental problems in a telecoupled world.

[1] The scholarly database Scopus lists two publications with telecoup* in any search field pre-2013, and 161 publications in
2018 alone, with substantial increases with every year (search performed on 21 August 2019).

${ }^{[2]}$ Elsewhere, we have referred to this perspective as "governance inducing telecoupling" (Newig et al. 2019).

Responses to this article can be read online at: http://www.ecologyandsociety.org/issues/responses. $\mathrm{php} / 11844$

\section{Acknowledgments:}

This work was funded by the German Research Foundation (DFG) under grants no. CH 1643/2-1, LE 2396/4-1 and NE 1207/7-1 through the project "GOVERNECT - Governance of Environmental Sustainability in Telecoupled Systems of Global Inter-Regional Connectedness" (see https://sustainability-governance. net/governect). Earlier versions of this paper were presented at a workshop on "Governance in Telecoupled Land Systems," University of Berne, 19-20 April 2018; the panel on Governing Environmental Sustainability in a Globally 'Telecoupled' World, ECPR General Conference, Hamburg, 22-25 August 2018; and at the Earth System Governance Conference, Utrecht, 5-8 November. We thank the participants of these workshops and in particular Christoph Oberlack, Philipp Pattberg, and Johanna Coenen for helpful comments on earlier drafts.

Data Availability:

Datalcode sharing is not applicable to this article because no new datalcode were created or analyzed in this study.

\section{LITERATURE CITED}

Abbott, K. W., and D. Snidal. 2009. Strengthening international regulation through transnational new governance: overcoming the orchestration deficit. Vanderbilt Journal of Transnational Law 42:501-578.

Andonova, L. B., and R. B. Mitchell. 2010. The rescaling of global environmental politics. Annual Review of Environment and Resources 35:255-282. https://doi.org/10.1146/annurevenviron-100809-125346

Bächtiger, A., J. S. Dryzek, J. Mansbridge, and M. E. Warren, editors. 2018. The Oxford handbook of deliberative democracy. Oxford University Press, Oxford, UK. https://doi.org/10.1093/ oxfordhb/9780198747369.001.0001

Bair, J. 2009. Global commodity chains: genealogy and review. Pages 1-35 in J. Bair, editor. Frontiers of commodity chain research. Stanford University Press, Palo Alto, California, USA.

Balsiger, J., and M. Prys. 2016. Regional agreements in international environmental politics. International Environmental Agreements: Politics, Law and Economics 16:239-260. https://doi. org/10.1007/s10784-014-9256-3

Barkin, J. S., and G. E. Shambaugh, editors. 1999. Anarchy and the environment: the international relations of the common pool resources. State University of New York Press, Albany, New York, USA. 
Bernauer, T. 1997. Managing international rivers. Pages 155-196 in O. R. Young, editor. Global governance. Drawing insights from the environmental experience. The MIT Press, Cambridge, Massachusetts, USA.

Biermann, F. 2007. 'Earth system governance' as a crosscutting theme of global change research. Global Environmental Change 17:326-337. https://doi.org/10.1016/j.gloenvcha.2006.11.010

Biermann, F. 2014. Earth system governance: world politics in the Anthropocene. The MIT Press, Cambridge, Massachusetts, USA. https://doi.org/10.7551/mitpress/9780262028226.001.0001

Biermann, F., and S. Bauer, editors. 2005. A world environment organization: solution or threat for effective international environmental governance? Ashgate, Aldershot, UK. https://doi. org/10.4324/9781315263564

Black, J. 2008. Constructing and contesting legitimacy and accountability in polycentric regulatory regimes. Regulation and Governance 2:137-164. https://doi.org/10.1111/j.1748-5991.2008.00034. $\underline{\mathrm{X}}$

Blatter, J. 1997. Explaining crossborder cooperation: a borderfocused and border-external approach. Journal of Borderlands Studies 12:151-174. https://doi.org/10.1080/08865655.1997.9695502

Boas, I., F. Biermann, and N. Kanie. 2016. Cross-sectoral strategies in global sustainability governance: towards a nexus approach. International Environmental Agreements: Politics, Law and Economics 16:449-464. https://doi.org/10.1007/s10784-016-9321-1

Boas, I., S. Kloppenburg, J. van Leeuwen, and M. Lamers. 2018. Environmental mobilities: an alternative lens to global environmental governance. Global Environmental Politics 18:107-126. https://doi.org/10.1162/glep a 00482

Bokpin, G. A. 2017. Foreign direct investment and environmental sustainability in Africa: the role of institutions and governance. Research in International Business and Finance 39(Part A):239-247. https://doi.org/10.1016/j.ribaf.2016.07.038

Bolwig, S., S. Ponte, A. du Toit, L. Riisgaard, and N. Halberg. 2010. Integrating poverty and environmental concerns into valuechain analysis: a conceptual framework. Development Policy Review 28:173-194. https://doi.org/10.1111/j.1467-7679.2010.00480. $\underline{\mathrm{x}}$

Buckley, P. J., and P. N. Ghauri. 2004. Globalisation, economic geography and the strategy of multinational enterprises. Journal of International Business Studies 35:81-98. https://doi. org/10.1057/palgrave.jibs. 8400076

Bueno, N. 2019. The Swiss popular initiative on responsible business: from responsibility to liability. Pages 239-258 in L. Enneking, I. Giesen, A.-J. Schaap, C. Ryngaert, F. Kristen, and L. Roorda, editors. Accountability, international business operations, and the law: providing justice for corporate human rights violations in global value chains. Routledge, Abingdon, UK. https://doi.org/10.4324/9781351127165-1

Bunker, S. G. 1984. Modes of extraction, unequal exchange, and the progressive underdevelopment of an extreme periphery: the Brazilian Amazon, 1600-1980. American Journal of Sociology 89:1017-1064. https://doi.org/10.1086/227983
Buntaine, M. T., and B. C. Parks. 2013. When do environmentally focused assistance projects achieve their objectives? Evidence from World Bank post-project evaluations. Global Environmental Politics 13(2):65-88. https://doi.org/10.1162/GLEP_a_00167

Burch, S., A. Gupta, C. Inoue, A. Kalfagianni, Å. Persson, A. K. Gerlak, A. Ishii, J. Patterson, J. Pickering, M. Scobie, J. van der Heijden, J. Vervoort, C. Adler, M. Bloomsfield, R. Djalante, J. Dryzek, V. Galaz, C. Gordon, R. Harmon, S. Jinnah, R. E. Kim, L. Olsson, J. Van Leeuwen, V. Ramasar, P. Wapner, and R. Zondervan. 2019. New directions in earth system governance research. Earth System Governance 1:100006. https://doi. org/10.1016/j.esg.2019.100006

Bush, S. R., P. Oosterveer, M. Bailey, and A. P. J. Mol. 2015. Sustainability governance of chains and networks: a review and future outlook. Journal of Cleaner Production 107:8-19. https:// doi.org/10.1016/j.jclepro.2014.10.019

Cashore, B. 2002. Legitimacy and the privatization of environmental governance: how non-state market-driven (NSMD) governance systems gain rule-making authority. Governance: An International Journal of Policy, Administration, and Institutions 15:503-529. https://doi.org/10.1111/1468-0491.00199

Castells, M. 1996. The information age: economy, society and culture, vol. 1: the rise of the network society. Blackwell, Cambridge, Massachusetts, USA.

Challies, E. 2013. The limits to voluntary private social standards in global agri-food system governance. International Journal of Sociology of Agriculture and Food 20:175-195.

Challies, E., J. Newig, and A. Lenschow. 2014. What role for social-ecological systems research in governing global teleconnections? Global Environmental Change 27:32-40. https:// doi.org/10.1016/j.gloenvcha.2014.04.015

Charnovitz, S. 1997. The World Trade Organization and the environment. Yearbook of International Environmental Law 8:98-116. https://doi.org/10.1093/yiel/8.1.98

Cheyns, E. 2011. Multi-stakeholder initiatives for sustainable agriculture: limits of the 'inclusiveness' paradigm. Pages 318-354 in S. Ponte, J. Vestergaard, and P. Gibbon, editors. Governing through standards: Origins, drivers and limits. Palgrave, London, UK.

Clapp, J., and P. Dauvergne. 2011. Paths to a green world: the political economy of the global environment. Second edition. The MIT Press, Cambridge, Massachusetts, USA. https://doi. org/10.7551/mitpress/5265.001.0001

Conca, K. 2012. The rise of the region in global environmental politics. Global Environmental Politics 12:127-133. https://doi. org/10.1162/GLEP a 00132

Corson, C. 2010. Shifting environmental governance in a neoliberal world: U.S. AID for conservation. Antipode 42 (3):576-602. https://doi.org/10.1111/j.1467-8330.2010.00764.x

Dauvergne, P. 2008. The shadows of consumption: consequences for the global environment. The MIT Press, Cambridge, Massachusetts, USA. https://doi.org/10.7551/mitpress/7706.001.0001

Dauvergne, P. 2010. The problem of consumption. Global Environmental Politics 10:1-10. https://doi.org/10.1162/glep.2010.10.2.1 
Dauvergne, P., editor. 2012. Handbook of global environmental politics. Second edition. Edward Elgar, Cheltenham, UK. https:// doi.org/10.4337/9781845425555

Dauvergne, P., and J. Clapp. 2016. Researching global environmental politics in the 21st century. Global Environmental Politics 16:1-12. https://doi.org/10.1162/GLEP e 00333

Dauvergne, P., and J. Lister. 2010. The power of big box retail in global environmental governance: bringing commodity chains back into IR. Millennium: Journal of International Studies 39:145-160. https://doi.org/10.1177/0305829810371018

Dauvergne, P., and J. Lister. 2012. Big brand sustainability: governance prospects and environmental limits. Global Environmental Change 22:36-45. https://doi.org/10.1016/j. gloenvcha.2011.10.007

Derkx, B., and P. Glasbergen. 2014. Elaborating global private meta-governance: an inventory in the realm of voluntary sustainability standards. Global Environmental Change 27:41-50. https://doi.org/10.1016/j.gloenvcha.2014.04.016

Dolan, C., and J. Humphrey. 2004. Changing governance patterns in the trade in fresh vegetables between Africa and the United Kingdom. Environment and Planning A 36:491-509. https://doi. org/10.1068/a35281

Eakin, H., R. DeFries, S. Kerr, E. F. Lambin, J. Liu, P. J. Marcotullio, P. Messerli, A. Reenberg, X. Rueda, S. R. Swaffield, B. WIcke, and K. Zimmerer. 2014. Significance of telecoupling for exploration of land-use change. Pages 141-161 in K. C. Seto and A. Reenberg, editors. Rethinking global land use in an urban era. The MIT Press, Cambridge, Massachusetts, USA. https:// doi.org/10.7551/mitpress/9780262026901.003.0008

Eakin, H., X. Rueda, and A. Mahanti. 2017. Transforming governance in telecoupled food systems. Ecology and Society 22 (4):32. https://doi.org/10.5751/ES-09831-220432

Earle, A., A. Jägerskog, and J. Öjendal, editors. 2010. Transboudary water management. Principles and practice. Earthscan, London, UK.

Eckersley, R. 2004. The big chill: the WTO and multilateral environmental agreements. Global Environmental Politics 4:24-50. https://doi.org/10.1162/152638004323074183

Elgert, L. 2012. Certified discourse? The politics of developing soy certification standards. Geoforum 43:295-304. https://doi. org/10.1016/j.geoforum.2011.08.008

Esty, D. C. 1994. The case for a global environmental organization. Pages 287-309 in P. Kenen, editor. Managing the world economy: fifty years after Bretton Woods. Columbia University Press, New York, New York, USA.

Evans, P. 1997. The eclipse of the state? Reflections on stateness in an era of globalization. World Politics 50:62-87. https://doi. org/10.1017/S0043887100014726

Fortin, E. 2013. Transnational multi-stakeholder sustainability standards and biofuels: understanding standards processes. Journal of Peasant Studies 40(3):563-587. https://doi. org/10.1080/03066150.2013.796455

Frey, R. S., P. K. Gellert, and H. F. Dahms, editors. 2019. Ecologically unequal exchange: environmental injustice in comparative and historical perspective. Springer, Cham, Switzerland. https://doi.org/10.1007/978-3-319-89740-0

Friis, C., and J. Ø. Nielsen. 2017. On the system. Boundary choices, implications, and solutions in telecoupling land use change research. Sustainability 9:974. https://doi.org/10.3390/ $\underline{\text { su9060974 }}$

Friis, C., J. Ø. Nielsen, I. Otero, H. Haberl, J. Niewöhner, and P. Hostert. 2016. From teleconnection to telecoupling: taking stock of an emerging framework in land system science. Journal of Land Use Science 11:131-153. https://doi.org/10.1080/1747423X.2015.1096423

Fuchs, D., A. Kalfagianni, and T. Havinga. 2011. Actors in private food governance: the legitimacy of retail standards and multistakeholder initiatives with civil society participation. Agriculture and Human Values 28:353-367. https://doi. org/10.1007/s10460-009-9236-3

Galaz, V., P. Olsson, T. Hahn, C. Folke, and U. Svedin. 2008. The problem of fit among biophysical systems, environmental and resource regimes, and broader governance systems: insights and emerging challenges. Pages 147-186 in O. R. Young, L. A. King, and $\mathrm{H}$. Schroeder, editors. Institutions and environmental change. principal findings, applications, and research frontiers. The MIT Press, Cambridge, Massachusetts, USA. https://doi.org/10.7551/ mitpress/9780262240574.003.0005

Gardner, T. A., M. Benzie, J. Börner, E. Dawkins, S. Fick, R. Garrett, J. Godar, A. Grimard, S. Lake, R. K. Larsen, N. Mardas, C. L. McDermott, P. Meyfroidt, M. Osbeck, M. Persson, T. Sembres, C. Suavet, B. Strassburg, A. Trevisan, C. West, and P. Wolvekamp. 2019. Transparency and sustainability in global commodity supply chains. World Development 121:163-177. https://doi.org/10.1016/j.worlddev.2018.05.025

Gehring, T. 2007. Einflussbeziehungen zwischen internationalen Institutionen im Spannungsfeld von Handel und Umwelt: von gegenseitiger Störung zur institutionalisierten Arbeitsteilung zwischen internationalen Umweltinstitutionen und der Welthandelsorganisation. Politische Vierteljahresschrift Sonderheft 39/2007:94-114.

Gereffi, G. 1994. The organization of buyer-driven global commodity chains: how U.S. retailers shape overseas production networks. Pages 95-122 in G. Gereffi and M. Korzeniewicz, editors. Commodity chains and global capitalism. Praeger, Westport, Connecticut, USA.

Gereffi, G. 1999. International trade and industrial upgrading in the apparel commodity chain. Journal of International Economics 48:37-70. https://doi.org/10.1016/S0022-1996(98)00075-0

Gereffi, G., J. Humphrey, and T. Sturgeon. 2005. The governance of global value chains. Review of International Political Economy 12:78-104. https://doi.org/10.1080/09692290500049805

German, L. 2014. Multi-sited governance of large-scale land acquisitions: mapping and evaluating the terrain. Review of Policy Research 31:218-252. https://doi.org/10.1111/ropr.12070

Gibbon, P., J. Bair, and S. Ponte. 2008. Governing global value chains: an introduction. Economy and Society 37:315-338. https:// doi.org/10.1080/03085140802172656

Gilligan, J. M., and M. P. Vandenbergh. 2020. A framework for assessing the impact of private climate governance. Energy 
Research and Social Science 60:101400. https://doi.org/10.1016/j. erss.2019.101400

Givens, J. E. 2018. Ecologically unequal exchange and the carbon intensity of well-being, 1990-2011. Environmental Sociology 4:311-324. https://doi.org/10.1080/23251042.2018.1436878

Haas, P. M. 1990. Saving the Mediterranean: the politics of international environmental cooperation. Columbia University Press, New York, New York, USA.

Haas, P. M. 2016. Regional environmental governance. Pages 430-456 in T. A. Boerzel and T. Risse, editors. The Oxford handbook of comparative regionalism. Oxford University Press, Oxford, UK.

Haas, P. M., R. O. Keohane, and M. A. Levy, editors. 1993. Institutions for the Earth: sources of effective international environmental protection. The MIT Press, Cambridge, Massachusetts, USA.

Haberl, H., C. Mbow, X. Deng, E. G. Irwin, S. Kerr, T. Kuemmerle, O. Mertz, P. Meyfroidt, and B. L. Turner II. 2014. Finite land resources and competition. Pages 35-69 in K. C. Seto and A. Reenberg, editors. Rethinking global land use in an urban era. The MIT Press, Cambridge, Massachusetts, USA. https:// doi.org/10.7551/mitpress/9780262026901.003.0004

Hamilton-Hart, N. 2015. Multilevel (mis)governance of palm oil production. Australian Journal of International Affairs 69:164-184. https://doi.org/10.1080/10357718.2014.978738

Harris, P. G., editor. 2014. Routledge handbook of global environmental politics. Routledge, London, UK. https://doi. org/10.4324/9780203799055

Havice, E., and L. Campling. 2017. Where chain governance and environmental governance meet: interfirm strategies in the canned tuna global value chain. Economic Geography 93:292-313. https://doi.org/10.1080/00130095.2017.1292848

Hoff, H. 2011. Understanding the nexus: background paper for the Bonn 2011 Nexus Conference: The Water, Energy and Food Security Nexus. Stockholm Environment Institute, Stockholm, Sweden.

Holzinger, K., C. Knill, and B. Arts. 2008. Environmental policy convergence in Europe: the impact of institutions and trade. Cambridge University Press, Cambridge, UK. https://doi. org/10.1017/CBO9780511491962

Hooghe, L., and G. Marks. 2003. Unraveling the central state, but how? Types of multi-level governance. American Political Science Review 97:233-243.

Hornborg, A. 1998. Towards an ecological theory of unequal exchange: articulating world system theory and ecological economics. Ecological Economics 25:127-136. https://doi. org/10.1016/S0921-8009(97)00100-6

Humphrey, J., and H. Schmitz. 2001. Governance in global value chains. IDS Bulletin 32:19-29. https://doi.org/10.1111/j.1759-5436.2001. mp32003003.x

Jager, N. W. 2016. Transboundary cooperation in European water governance: a set-theoretic analysis of international river basins. Environmental Policy and Governance 26:278-291. https://doi. org/10.1002/eet.1717
Jordan, A. 2008. The governance of sustainable development: taking stock and looking forwards. Environment and Planning $C$ 26:17-33. https://doi.org/10.1068/cav6

Jörgens, H., A. Lenschow, and D. Liefferink, editors. 2014. Understanding environmental policy convergence. The power of words, rules and money. Cambridge University Press, Cambridge, UK. https://doi.org/10.1017/CBO9781139795357

Jorgenson, A. K. 2016. Environment, development, and ecologically unequal exchange. Sustainability 8(3):227. https:// doi.org/10.3390/su8030227

Kaplinsky, R., and M. Morris. 2002. A handbook for value chain research. Institute of Development Studies, University of Sussex, Brighton, England.

Kareiva, P., A. Chang, and M. Marvier. 2008. Environmental economics. Development and conservation goals in World Bank projects. Science 321(5896):1638-1639. https://doi.org/10.1126/ science. 1162756

Keohane, R. O. 1984. After hegemony: cooperation and discord in the world political economy. Princeton University Press, Princeton, New Jersey, USA.

Kissinger, M., W. E. Rees, and V. Timmer. 2011. Interregional sustainability: governance and policy in an ecologically interdependent world. Environmental Science \& Policy 14:965-976. https://doi.org/10.1016/j.envsci.2011.05.007

Krapivin, V. F., and C. A. Varotsos. 2007. Globalization and sustainable development - environmental agendas. Springer, Berlin, Germany.

Lange, P., P. P. J. Driessen, A. Sauer, B. Bornemann, and P. Burger. 2013. Governing towards sustainability - conceptualizing modes of governance. Journal of Environmental Policy and Planning 15 (3):403-425. https://doi.org/10.1080/1523908X.2013.769414

Lemos, M. C., and A. Agrawal. 2006. Environmental governance. Annual Review of Environment and Resources 31:297-325. https:// doi.org/10.1146/annurev.energy.31.042605.135621

Lenschow, A., J. Newig, and E. Challies. 2016. Globalization's limits to the environmental state? Integrating telecoupling into global environmental governance. Environmental Politics 25:136-159. https://doi.org/10.1080/09644016.2015.1074384

Liu, J., Y. Dou, M. Batistella, E. Challies, T. Connor, C. Friis, J. D. A. Millington, E. Parish, C. L. Romulo, R. F. B. Silva, H. Triezenberg, H. Yang, Z. Zhao, K. S. Zimmerer, F. Huettmann, M. L. Treglia, Z. Basher, M. G. Chung, A. Herzberger, A. Lenschow, A. Mechiche-Alami, J. Newig, J. Roche, and J. Sun. 2018. Spillover systems in a telecoupled Anthropocene: typology, methods, and governance for global sustainability. Current Opinion in Environmental Sustainability 33:58-69. https://doi. org/10.1016/j.cosust.2018.04.009

Liu, J., V. Hull, M. Batistella, R. DeFries, T. Dietz, F. Fu, T. W. Hertel, R. C. Izaurralde, E. F. Lambin, S. Li, L. A. Martinelli, W. J. McConnell, E. F. Moran, R. Naylor, Z. Ouyang, K. R. Polenske, A. Reenberg, G. de Miranda Rocha, C. S. Simmons, P. H. Verburg, P. M. Vitousek, F. Zhang, and C. Zhu. 2013. Framing sustainability in a telecoupled world. Ecology and Society 18 (2):26. https://doi.org/10.5751/ES-05873-180226 
López Rivera, A. 2017. Chronicle of a schism foretold: the state and transnational activism in Ecuador's Yasuní-ITT initiative. Environmental Sociology 3:226-236. https://doi.org/10.1080/23251042.2017.1295836

Mak Arvin, B., and B. Lew. 2009. Foreign aid and ecological outcomes in poorer countries: an empirical analysis. Applied Economics Letters 16(3):295-299. https://doi.org/10.1080/13504$\underline{850601018312}$

Martinot, E. 2001. World Bank energy projects in China: influences on environmental protection. Energy Policy 29 (8):581-594. https://doi.org/10.1016/S0301-4215(00)00152-X

May, P. J., J. Sapotichne, and S. Workman. 2006. Policy coherence and policy domains. Policy Studies Journal 34:381-403. https:// doi.org/10.1111/j.1541-0072.2006.00178.x

Meadowcroft, J. 2007. Who is in charge here? Governance for sustainable development in a complex world. Journal of Environmental Policy \& Planning 9:299-314. https://doi. org/10.1080/15239080701631544

Meadows, J., M. Annandale, and L. Ota. 2019. Indigenous peoples' participation in sustainability standards for extractives. Land Use Policy 88:104118. https://doi.org/10.1016/j. landusepol.2019.104118

Miles, E. L., A. Underdal, S. Andresen, J. Wettestad, J. B. Skjaerseth, and E. M. Carlin. 2002. Environmental regime effectiveness: confronting theory with evidence. The MIT Press, Cambridge, Massachusetts, USA. https://doi.org/10.7551/ mitpress/2784.001.0001

Mitchell, R. B. 2013. Oran Young and international institutions. International Environmental Agreements: Politics, Law and Economics 13:1-14. https://doi.org/10.1007/s10784-012-9200-3

Mol, A. P. J. 2006. Environmental governance in the information age: the emergence of informational governance. Environment and Planning C: Government and Policy 24:497-514. https://doi. org/10.1068/c0508j

Mol, A. P. J. 2015. Transparency and value chain sustainability. Journal of Cleaner Production 107:154-161. https://doi. org/10.1016/j.jclepro.2013.11.012

Mol, A. P. J. 2016. The environmental nation state in decline. Environmental Politics 25:48-68. https://doi.org/10.1080/096440$\underline{16.2015 .1074385}$

Mol, A. P. J., and P. Oosterveer. 2015. Certification of markets, markets of certificates: tracing sustainability in global agro-food value chains. Sustainability 7:12258-12278. https://doi.org/10.3390/ $\underline{\text { su70912258 }}$

Mol, A. P. J., and G. Spaargaren. 2012. Global environmental politics and governance: a networks and flows perspective Pages 194-209 in P. Dauvergne, editor. Handbook of global environmental politics. Edward Elgar, Cheltenham, UK. https://doi. org/10.4337/9781849809412.00025

Mol, A. P. J., G. Spaargaren, and D. A. Sonnenfeld. 2013. Ecological modernization theory: taking stock, moving forward. Pages 15-30 in S. Lockie, D. A. Sonnenfeld, and D. R. Fisher, editors. Routledge international handbook of social and environmental change. Routledge, London, UK. https://doi. org/10.4324/9780203814550.ch2

Nawrotzki, R. J., F. Riosmena, L. M. Hunter, and D. M. Runfola. 2015. Amplification or suppression: social networks and the climate change-migration association in rural Mexico. Global Environmental Change 35:463-474. https://doi.org/10.1016/j. gloenvcha.2015.09.002

Newig, J., E. Challies, N. W. Jager, E. Kochskämper, and A. Adzersen. 2018. The environmental performance of participatory and collaborative governance: a framework of causal mechanisms. Policy Studies Journal 46:269-297. https://doi. org/10.1111/psj.12209

Newig, J., and O. Fritsch. 2009. Environmental governance: participatory, multi-level - and effective? Environmental Policy and Governance 19:197-214. https://doi.org/10.1002/eet.509

Newig, J., A. Lenschow, E. Challies, B. Cotta, and A. SchillingVacaflor. 2019. What is governance in global telecoupling? Ecology and Society 24(3):26. https://doi.org/10.5751/es-11178-240326

Newig, J., and T. Moss. 2017. Scale in environmental governance: moving from concepts and cases to consolidation. Journal of Environmental Policy \& Planning 19:473-479. https://doi. org/10.1080/1523908X.2017.1390926

Nilsson, M., M. Pallemaerts, and I. von Homeyer. 2009. International regimes and environmental policy integration: introducing the special issue. International Environmental Agreements: Politics, Law and Economics 9:337. https://doi. org/10.1007/s10784-009-9108-8

O'Neill, K. 2009. The environment and international relations. Cambridge University Press, Cambridge, UK. https://doi. org/10.1017/9781107448087

Oates, W. E. 2004. Environmental policy and fiscal Federalism. Selected essays of Wallace E. Oates. Edward Elgar, Cheltenham, UK.

Oberlack, C., S. Boillat, S. Brönnimann, J.-D. Gerber, A. Heinimann, C. Ifejika Speranza, P. Messerli, S. Rist, and U. Wiesmann. 2018. Polycentric governance in telecoupled resource systems. Ecology and Society 23(1):16. https://doi.org/10.5751/ ES-09902-230116

Oberthür, S., and T. Gehring, editors. 2006. Institutional interaction in global environmental governance: synergy and conflict among international and EU policies. The MIT Press, Cambridge, Massachusetts, USA. https://doi.org/10.7551/mitpress/3808.001.0001

Oberthür, S., and O. S. Stokke, editors. 2011. Managing institutional complexity: regime interplay and global environmental change. The MIT Press, Cambridge, Massachusetts, USA. https:// doi.org/10.7551/mitpress/9780262015912.001.0001

Okereke, C., and I. Stacewicz. 2018. Stakeholder perceptions of the environmental effectiveness of multi-stakeholder initiatives: evidence from the palm oil, soy, cotton, and timber programs. Society and Natural Resources 31:1302-1318. https://doi. org/10.1080/08941920.2018.1482037

Oosterveer, P. 2018. Global environmental networks and flows addressing global environmental change. Pages 95-118 in $\mathrm{M}$. 
Boström and D. J. Davidson, editors. Environment and society: concepts and challenges. Palgrave Macmillan, Cham, Switzerland. https://doi.org/10.1007/978-3-319-76415-3 5

Oswald, I., and A. Reller. 2011. E-Waste: a story of trashing, trading, and valuable resources. GAIA - Ecological Perspectives for Science and Society 20:41-47. https://doi.org/10.14512/ gaia.20.1.9

Pattberg, P. 2006. Private governance and the south: lessons from global forest politics. Third World Quarterly 27:579-593. https:// doi.org/10.1080/01436590600720769

Pattberg, P., and O. Widerberg. 2015. Theorising global environmental governance: key findings and future questions. Millennium: Journal of International Studies 43:684-705. https:// doi.org/10.1177/0305829814561773

Perrin, S., and T. Bernauer. 2010. International regime formation revisited: explaining ratification behaviour with respect to longrange transboundary air pollution agreements in Europe. European Union Politics 11:405-426. https://doi.org/10.1177/146$\underline{5116510373669}$

Phoochinda, W. 2018. Development of community network for sustainable tourism based on the green economy concept. Journal of Environmental Management and Tourism 9:1236-1243. https:// doi.org/10.14505//jemt.9.6(30).13

Plangger, M. 2019. Exploring the role of territorial actors in crossborder regions. Territory, Politics, Governance 7:156-176. https:// doi.org/10.1080/21622671.2017.1336938

Princen, T., and M. Finger. 1994. Environmental NGOs in world politics: linking the local and the global. Routledge, Abingdon, UK.

Reenberg, A., and N. A. Fenger. 2011. Note: globalizing land use transitions: the soybean acceleration. Geografisk TidsskriftDanish Journal of Geography 111:85-92. https://doi. org/10.1080/00167223.2011.10669524

Restivo, M., J. M. Shandra, and J. M. Sommer. 2018. The United States agency for international development and forest loss: a cross-national analysis of environmental aid. Social Science Journal 55(2):170-181. https://doi.org/10.1016/j.soscij.2017.09.001

Reyes-Mendy, F., R. A. Arriagada, S. Reyes-Paecke, and A. Tobar. 2014. Policy statement coherence: a methodological proposal to assess environmental public policies applied to water in Chile. Environmental Science \& Policy 42:169-180. https://doi. org/10.1016/i.envsci.2014.06.001

Rice, J. 2007. Ecological unequal exchange: consumption, equity, and unsustainable structural relationships within the global economy. International Journal of Comparative Sociology 48:43-72. https://doi.org/10.1177/0020715207072159

Rosa, E. A., and T. Dietz. 2012. Human drivers of national greenhouse-gas emissions. Nature Climate Change 2:581-586. https://doi.org/10.1038/nclimate1506

Schleifer, P. 2013. Orchestrating sustainability: the case of European Union biofuel governance. Regulation and Governance 7:533-546. https://doi.org/10.1111/rego.12037
Schleifer, P., M. Fiorini, and L. Fransen. 2019. Missing the bigger picture: a population-level analysis of transnational private governance organizations active in the global south. Ecological Economics 164:106362. https://doi.org/10.1016/j.ecolecon.2019.106362

Schouten, G., and P. Glasbergen. 2011. Creating legitimacy in global private governance: the case of the roundtable on sustainable palm oil. Ecological Economics 70:1891-1899. https:// doi.org/10.1016/j.ecolecon.2011.03.012

Shandra, J. M., H. Rademacher, and C. Coburn. 2016. The World Bank and organized hypocrisy? A cross-national analysis of structural adjustment and forest loss. Environmental Sociology 2 (2):192-207. https://doi.org/10.1080/23251042.2016.1160471

Shandra, J. M., M. Restivo, and J. M. Sommer. 2020. Appetite for destruction? China, ecologically unequal exchange, and forest loss. Rural Sociology 85:346-375. https://doi.org/10.1111/ $\underline{\text { ruso. } 12292}$

Sheppard, E. 2016. Limits to globalization: the disruptive geographies of capitalist development. Oxford University Press, Oxford, UK. https://doi.org/10.1093/acprof:oso/9780199681167.001.0001

Sikor, T., G. Auld, A. J. Bebbington, T. A. Benjaminsen, B. S. Gentry, C. Hunsberger, A.-M. Izac, M. E. Margulis, T. Plieninger, H. Schroeder, and C. Upton. 2013. Global land governance: from territory to flow? Current Opinion in Environmental Sustainability 5:522-527. https://doi.org/10.1016/j.cosust.2013.06.006

Sommer, J. M., M. Restivo, and J. M. Shandra. 2019. India, palm oil, and ecologically unequal exchange: a cross-national analysis of forest loss. Sociological Perspectives 63(2):312-332. https://doi. org/10.1177/0731121419888645

Sommer, J. M., J. M. Shandra, and M. Restivo. 2017. The World Bank, contradictory lending, and forests: a cross-national analysis of organized hypocrisy. International Sociology 32 (6):707-730. https://doi.org/10.1177/0268580917722893

Sonnenfeld, D. A., and A. P. J. Mol. 2002. Globalization and the transformation of environmental governance. An introduction. American Behavioral Scientist 45:1318-1339. https://doi. org/10.1177/0002764202045009003

Spaargaren, G., A. P. J. Mol, and F. H. Buttel, editors. 2006. Governing environmental flows. Global challenges to social theory. The MIT Press, Cambridge, Massachusetts, USA. https://doi. org/10.7551/mitpress/3333.001.0001

Speth, J. G., and P. M. Haas. 2006. Global environmental governance. Island, Washington, D.C., USA.

Stevenson, H. 2017. Global environmental politics: problems, policy, and practice. Cambridge University Press, Cambridge, UK. https://doi.org/10.1017/9781316344354

Thorlakson, T., J. Hainmueller, and E. F. Lambin. 2018. Improving environmental practices in agricultural supply chains: the role of company-led standards. Global Environmental Change 48:32-42. https://doi.org/10.1016/j.gloenvcha.2017.10.006

Turner II, B. L., R. E. Kasperson, W. B. Meyer, K. M. Dow, D. Golding, J. X. Kasperson, R. C. Mitchell, and S. J. Ratick. 1990. Two types of global environmental change. Definitional and 
spatial-scale issues in their human dimensions. Global Environmental Change 1:14-22. https://doi.org/10.1016/0959-3780 (90)90004-S

Urry, J. 2003. Global complexity. Polity Press, Cambridge, UK.

VanDeveer, S. D. 2015. Consumption, commodity chains, and global and local environments. Pages 350-372 in R. S. Axelrod and S. D. VanDeveer, editors. The global environment: institutions, law, and policy. SAGE/CQ Press, Thousand Oaks, California, USA.

Vongpraseuth, T., and C. G. Choi. 2015. Globalization, foreign direct investment, and urban growth management: policies and conflicts in Vientiane, Laos. Land Use Policy 42:790-799. https:// doi.org/10.1016/j.landusepol.2014.10.003

Vos, J., and R. Boelens. 2014. Sustainability standards and the water question. Development and Change 45:205-230. https://doi. org/10.1111/dech.12083

Voß, J.-P., J. Newig, B. Kastens, J. Monstadt, and B. Nölting. 2007. Steering for sustainable development: a typology of problems and strategies with respect to ambivalence, uncertainty and distributed power. Journal of Environmental Policy \& Planning 9:193-212. https://doi.org/10.1080/15239080701622881

York, R., E. A. Rosa, and T. Dietz. 2010. Ecological modernization theory: theoretical and empirical challenges. Pages 77-90 in M. R. Redclift and G. Woodgate, editors. The international handbook of environmental sociology. Edward Elgar, Cheltenham, UK. https://doi.org/10.4337/9781849805520.00014

Young, O. R. 1996. Institutional linkages in international society: polar perspectives. Global Governance 2:1-23. https://doi. org/10.1163/19426720-002-01-90000002

Young, O. R. 1998. Creating regimes: Arctic accords and international governance. Cornell University Press, Ithaca, New York, USA. https://doi.org/10.7591/9781501711411

Young, O. R. 2002. The institutional dimensions of environmental change: fit, interplay, and scale. The MIT Press, Cambridge, Massachusetts, USA. https://doi.org/10.7551/mitpress/3807.001.0001

Young, O. R., F. Berkhout, G. C. Gallopin, M. A. Janssen, E. Ostrom, and S. van der Leeuw. 2006. The globalization of socioecological systems: an agenda for scientific research. Global Environmental Change 16:304-316. https://doi.org/10.1016/j. gloenvcha.2006.03.004

Young, O. R., L. A. King, and H. Schroeder, editors. 2008. Institutions an environmental change: principal findings, applications and research frontiers. The MIT Press, Cambridge, Massachusetts, USA. https://doi.org/10.7551/mitpress/9780262$\underline{240574.001 .0001}$

Young, O. R., and O. S. Stokke. 2020. Why is it hard to solve environmental problems? The perils of institutional reductionism and institutional overload. International Environmental Agreements: Politics, Law and Economics 20(1):5-19. https://doi. org/10.1007/s10784-020-09468-6
Zelli, F., and H. van Asselt. 2013. The institutional fragmentation of global environmental governance: causes, consequences, and responses. Global Environmental Politics 13:1-13. https://doi. org/10.1162/GLEP_a_00180

Zürn, M. 1998. The rise of international environmental politics: a review of current research. World Politics 50:617-649. https:// doi.org/10.1017/S0043887100007383 